\title{
Boolean Control of Aptamer States
}

Dmitry M. Kolpashchikov and Milan N. Stojanovic ${ }^{\mathrm{a}^{*}}$

Supplementary Matereal

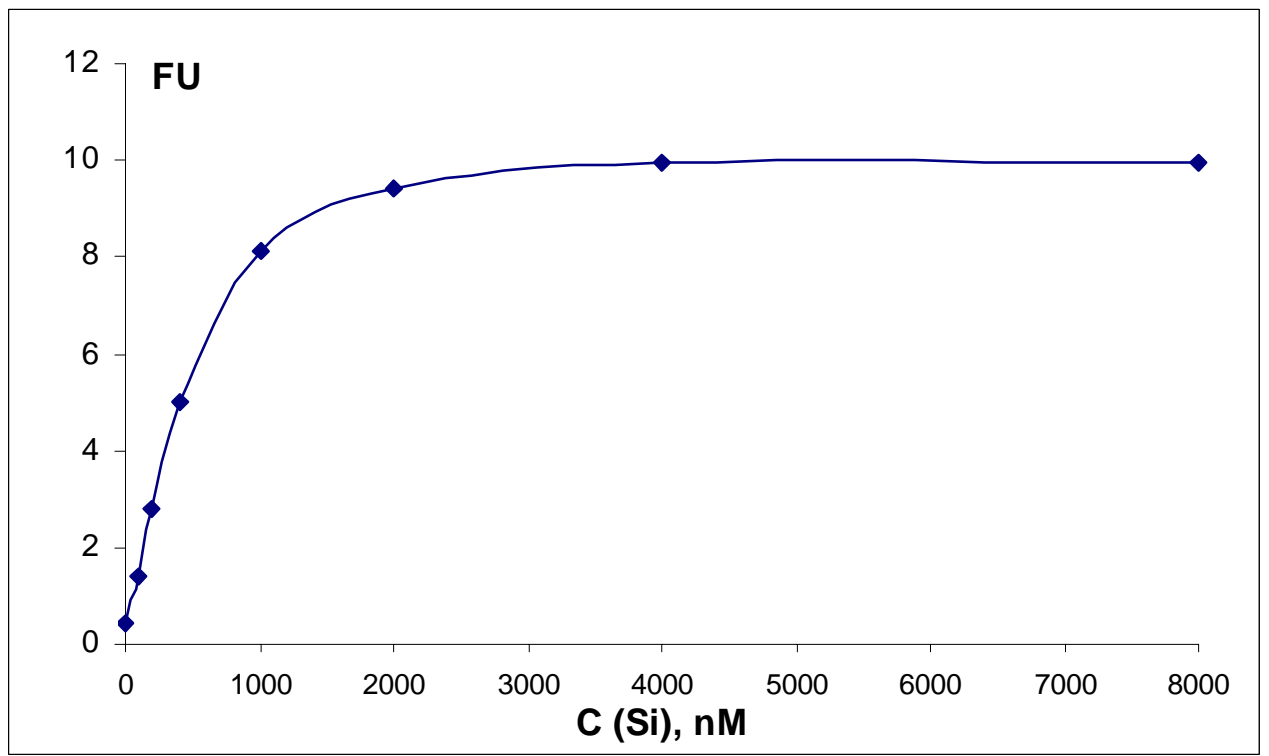

The dependence of fluorescence intensity of MG/anti MG aptamer complex at $648 \mathrm{nM}$ on Si concentration. MG $(0.3 \mu \mathrm{M})$ and anti MG aptamer $(1 \mu \mathrm{M})$ were incubated in buffer $\left(50 \mathrm{mM}\right.$ Tris $\mathrm{HCl}, \mathrm{pH}=7.4,50 \mathrm{mM} \mathrm{MgCl}_{2}, 1$ $\mathrm{mM} \mathrm{NaCl}$ ) in the presence of varying $\mathbf{S i}$ concentrations, followed by recording the fluorescence emmiting spectra. 